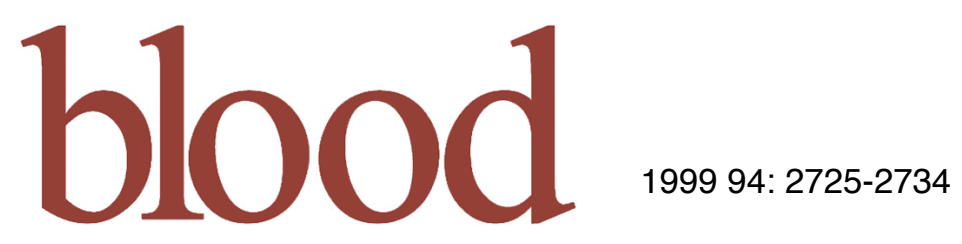

\title{
Circulating Activated Platelets Assist THP-1 Monocytoid/Endothelial Cell Interaction Under Shear Stress
}

Gregor Theilmeier, Tim Lenaerts, Claude Remacle, Désiré Collen, Jos Vermylen and Marc F. Hoylaerts

Updated information and services can be found at:

http://bloodjournal.hematologylibrary.org/cgi/content/full/94/8/2725

Articles on similar topics may be found in the following Blood collections:

Hemostasis, Thrombosis, and Vascular Biology (2496 articles)

Information about reproducing this article in parts or in its entirety may be found online at:

http://bloodjournal.hematologylibrary.org/misc/rights.dtl\#repub_requests

Information about ordering reprints may be found online at:

http://bloodjournal.hematologylibrary.org/misc/rights.dtl\#reprints

Information about subscriptions and ASH membership may be found online at:

http://bloodjournal.hematologylibrary.org/subscriptions/index.dtl

Blood (print ISSN 0006-4971, online ISSN 1528-0020), is published semimonthly by the American Society of Hematology, 1900 M St, NW, Suite 200, Washington DC 20036.

Copyright 2007 by The American Society of Hematology; all rights reserved.

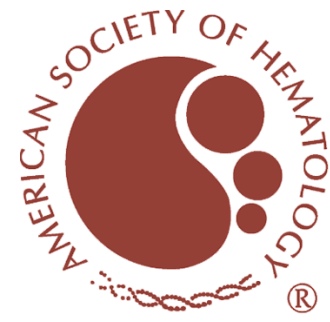


HEMOSTASIS, THROMBOSIS, AND VASCULAR BIOLOGY

\title{
Circulating Activated Platelets Assist THP-1 Monocytoid/Endothelial Cell Interaction Under Shear Stress
}

\author{
By Gregor Theilmeier, Tim Lenaerts, Claude Remacle, Désiré Collen, Jos Vermylen, and Marc F. Hoylaerts
}

\begin{abstract}
Circulating complexes of leukocytes and activated platelets are markers for atherosclerosis, but their interaction with the arterial endothelial lining has not been studied. Therefore, the effect of activated platelets on rolling and adhesion of labeled human THP-1 monocytoid cells to human umbilical vein endothelial cell (HUVEC) monolayers was studied by epifluorescence microscopy in a parallel plate flow chamber. In the absence of activated platelets, THP-1 rolling on resting HUVEC was negligible at shear rates greater than $300 \mathrm{~s}^{-1}$. Activation of HUVEC with $100 \mathrm{nmol} / \mathrm{L}$ phorbol myristate acetate (PMA) increased THP-1 cell adhesion at shear rates less than $400 \mathrm{~s}^{-1}$. Therefore, a shear rate of $400 \mathrm{~s}^{-1}$ was identified as a threshold for THP-1 adhesion. THP-1 rolling on activated HUVEC was reduced by $64 \%$ after L-selectin inhibition but was not affected by P-selectin inhibition. The addition of 1 to 50 thrombin receptor-activating peptide (TRAP)-activated platelets per THP-1 cell enhanced interactions between THP-1 cells and HUVEC, resulting in a steep bell-shaped dose-response curve, with a peak of $10 \pm 3$
\end{abstract}

$\mathbf{P}$ ATELETS HAVE BEEN implicated in the early development and the progression of atherosclerosis. After plaque rupture, platelets adhere to the prothrombotic material of the plaque interior and set off the cascade of thrombus formation and vessel occlusion. ${ }^{1-3}$ A contribution of platelets to endothelial injury and leukocyte extravasation into the subendothelial space during the early stages of atherogenesis before any morphological changes of the vessel wall can be observed has been postulated, but the mechanism of the phenomenon remains to be defined. ${ }^{4,5}$

Activated platelets mediate leukocyte/endothelial cell interactions, such as lymphocyte rolling on high endothelial venules of lymphnodes. ${ }^{6}$ Platelets roll on P-selectin expressed by endothelial cells in mesenteric venules in vivo. ${ }^{7}$ Platelets adherent to subendothelial matrix components support rolling, adhesion, and transmigration of leukocytes. ${ }^{8,9}$ Furthermore, platelets deposited on subendothelial matrix exposed between shear stress strained human umbilical vein endothelial cells (HUVEC) have been reported to mediate leukocyte delivery to the endothelial cells. ${ }^{10}$

Circulating activated platelets and leukocytes have been observed in animal models and in patient populations at risk for atherosclerosis. ${ }^{11-14}$ Increased levels of low-density lipoprotein (LDL) cholesterol induce platelet activation, as assessed by expression of P-selectin. ${ }^{15}$ Expression of adhesion molecules on endothelial cells is increased in conditions predisposing to atherosclerosis. ${ }^{16,17}$ Circulating complexes of activated platelets and leukocytes have been observed in unstable angina pectoris ${ }^{18}$ and after mechanical revascularization of stenosed coronary arteries, ${ }^{19,20}$ suggesting that they may be markers of vessel wall disease and thrombogenic atherosclerotic lesions.

Injection of chemically oxidized LDL into hamsters induced complex formation between platelets and granulocytes and increased leukocyte rolling on microvascular endothelium ex- rolling cells $/ 50$ seconds at 3 platelets per THP- 1 cell $(P<.01 v$ control) with a concomitant 2- to 3 -fold increase of firmly adhering cells $(P<.01 v$ control). In reconstituted blood, low numbers of activated platelets had the same effect on THP-1 rolling and adhesion. P-selectin inhibition reduced platelet/ THP-1 cell interaction in suspension and deposition of the complexes on the endothelial monolayer. Inhibition of both $P$ - and L-selectin reduced THP-1/HUVEC interactions to $14 \%$ $(P<.01, n=4)$. Sialidase digestion and removal of terminal sialic acid residues from HUVEC or THP-1 cells but not from platelets abolished the platelet mediated augmentation of THP-1 cell adhesion. Thus, THP-1 rolling on HUVEC is sheardependent and largely mediated by L-selectin. P-selectin expressed on activated platelets increases monocytoid cell adhesion to endothelial cells at shear rates found in coronary arteries through interactions with both endothelial and monocytoid cells and may facilitate macrophage accumulation in the vessel wall.

(c) 1999 by The American Society of Hematology.

posed in a skinfold chamber. ${ }^{21}$ Thus, circulating activated platelets may deliver leukocytes to the vessel wall under low shear conditions. The functional consequences of circulating leukocyte/platelet complexes, their adhesive properties, and the adhesion molecules involved in their delivery to the arterial vessel wall have not yet been elucidated.

The present study evaluates whether circulating activated platelets form complexes with monocytes and thereby enable the adhesion of monocytes to endothelial cells under shear conditions present in the arterial circulation. A videomicroscopic in vitro system was used, employing cosuperfusion over resting or activated HUVEC of activated human platelets and the human monocytoid cell line THP-1.

From the Center for Molecular and Vascular Biology, Katholieke Universiteit Leuven, Leuven, Belgium; and the Laboratoire de Biologie Cellulaire, Universite Catholique de Louvain, Louvain-la-Neuve, Belgium.

Submitted December 14, 1998; accepted June 14, 1999.

Supported by the Interuniversitaire Attractiepolen, (P4/34). J.V. is holder of the Dr. J. Choay Chair in Hemostasis Research. G.T. is on temporary leave from the Department for Anesthesiology and Surgical Intensive Care Medicine, Faculty of Medicine, University of Münster Germany. G.T. received a postdoctoral fellowship from the IMF, University of Münster, Germany.

Address reprint requests to Marc F. Hoylaerts, PhD, Center for Molecular and Vascular Biology, Katholieke Universiteit Leuven, Campus Gasthuisberg, O\&N, Herestraat 49, B-3000 Leuven, Belgium; e-mail:marc.hoylaerts@med.kuleuven.ac.be.

The publication costs of this article were defrayed in part by page charge payment. This article must therefore be hereby marked "advertisement" in accordance with 18 U.S.C. section 1734 solely to indicate this fact.

(1) 1999 by The American Society of Hematology.

0006-4971/99/9408-0015\$3.00/0 


\section{MATERIALS AND METHODS}

Reagents and materials. Cell culture reagents, medium 199, RPMI 1640, Hank's balanced salt solution (HBSS), phosphate-buffered saline (PBS), trypsin/EDTA, fetal bovine serum and penicillin/streptomycin $(10,000 / 10,000 \mathrm{U} / \mathrm{mL})$ were purchased from GIBCO, Lifetechnologies Inc (Paisley, UK). Human serum was from Biowhittaker (Walkersville, MD). Paraformaldehyde and microscopic glass coverslips $24 \times 50 \mathrm{~mm}$ from VEL (Haasrode, Belgium) were sterilized in $70 \%$ propanol and washed in PBS. Tissue culture dishes were from Becton Dickinson Labware (Maylan Cedex, France) and uncoated Petri dishes were from Sterilin (Suffordshire, UK). For flow chamber experiments, rinsing of HUVEC monolayers and preparation of the cell suspensions, $1 \%$ bovine serum albumin (Boehringer Mannheim, Mannheim, Germany), 200 $\mu \mathrm{g} / \mathrm{mL}$ purified human fibrinogen, $2 \mathrm{mmol} / \mathrm{L} \mathrm{CaCl}_{2}$, and $2 \mathrm{mmol} / \mathrm{L}$ $\mathrm{MgCl}_{2}$ (Sigma, St Louis, MO) were added to HBSS. This buffer is referred to as binding buffer throughout the text. Tissue culture grade calf skin collagen I was purchased from Boehringer Mannheim. Neuraminidase (sialidase at $1 \mathrm{U} / 100 \mu \mathrm{L}$ ) was from Boehringer Mannheim or Sigma. For the preparation of $\mathrm{pH} 6.5 \mathrm{ACD}, \mathrm{Na}_{3}$-citrate (75 $\mathrm{mmol} / \mathrm{L})$ and dextrose $(100 \mathrm{mmol} / \mathrm{L})$ were purchased from VEL. Citric acid $(38 \mathrm{mmol} / \mathrm{L})$ was obtained from Sigma. Phorbol myristate acetate (PMA) was dissolved in dimethyl sulfoxide (DMSO), stored at $-20^{\circ} \mathrm{C}$, and added to media 1:1,000 for a final concentration of $100 \mathrm{nmol} / \mathrm{L}$ to activate HUVEC. 2', 7'-bis-(2-carboxyethyl)-5-(and-6)-carboxyfluorescein-acetoxymethyl ester (BCECF-AM; Molecular Probes Europe, Leiden, The Netherlands) was dissolved in DMSO, aliquoted, and stored at $-20^{\circ} \mathrm{C}$ until used. The 14 amino acid form (S-F-L-L-R-N-P-ND-K-Y-E-P-F) of thrombin receptor-activating peptide (TRAP) was either purchased from Sigma or custom-synthesized by Eurogentech (Seraing, Belgium).

Monoclonal antibodies. The L-selectin blocking ${ }^{22}$ monoclonal antibody DREG56 (mouse IgG1; Endogen, Woburn, MA) was used at 2.5 $\mu \mathrm{g} / \mathrm{mL}$. The monoclonal anti-P-selectin antibody CLB-Thromb $/ 6^{23}$ (mouse IgG1; Immunotech, Marseille, France) was used at concentrations ranging from 0 to $2.5 \mu \mathrm{g} / \mathrm{mL}$. For fluorescence-activated cell sorting (FACS) analysis of P-selectin expression, the same antibody was purchased as fluorescein isothiocyanate (FITC) conjugate. The anti-CD34 control antibody, Birma-K3 ${ }^{24}$ (mouse IgG1; Dako, Glostrup, Denmark) was used at concentrations corresponding to those of the blocking antibodies. The anti-GP IIb/IIIa antibody MA-16N7C2 was raised and characterized in our laboratory as described elsewhere. ${ }^{25}$ The GPIb blocking antibody G19H10F6 was raised against the soluble GPIb domain glycocalicin by immunization of mice according to standard techniques. ${ }^{26,27}$ This antibody specifically binds to GPIb in enzymelinked immunosorbent assay (ELISA) and blocks ristocetin- and botrocetin-induced platelet aggregation. von Willebrand factordependent platelet deposition on coated collagen at $1,300 \mathrm{~s}^{-1}$ was inhibited by this antibody in flow chamber experiments with an $\mathrm{IC}_{50}$ of $5 \mu \mathrm{g} / \mathrm{mL}$. The RGD-mimetic G4120, used at $1 \mu \mathrm{g} / \mathrm{mL}$, was a generous gift from Genentech (San Francisco, CA).

Culture of HUVEC and THP-1. HUVEC were obtained by collagenase treatment ${ }^{28}$ and expanded in Medium 199 supplemented with $10 \%$ fetal bovine serum, $10 \%$ human serum, $100 \mathrm{U}$ penicillin, and $100 \mathrm{U}$ streptomycin on gelatin-coated dishes and frozen in liquid nitrogen after 2 passages. HUVEC were grown to confluency in tissue culture flasks coated with calf skin collagen I, trypsinized, and homogeneously seeded at high density on collagen-coated glass coverslips placed in noncoated Petri dishes. HUVEC were used at passage 3 to 5 for perfusion experiments. Cells were allowed to adhere for 2 hours before media was added and cells were grown to confluency on the coverslip. Whenever indicated, HUVEC were activated 4 hours before the experiment by the addition of $100 \mathrm{nmol} / \mathrm{L}$ PMA to the media. Coverslips were then carefully rinsed with binding buffer and mounted in the flow chamber. Confluency of each coverslip was confirmed microscopically before and after perfusion.

THP-1 cells were maintained in suspension in RPMI 1640 supplemented with $10 \%$ fetal calf serum, $100 \mathrm{U}$ penicillin, and $100 \mathrm{U}$ streptomycin. Cells were maintained at densities between 0.2 and $1.0 \times$ $10^{6} / \mathrm{mL}$. Before perfusions, cells were washed and resuspended in HBSS. Trypan blue exclusion showed a viability of greater than $98 \%$. BCECF-AM $(1 \mu \mathrm{mol} / \mathrm{L})$ was added to $1 \times 10^{6} \mathrm{THP}-1 / \mathrm{mL}$ in HBSS for 45 minutes at $37^{\circ} \mathrm{C}$. After labeling, cells were washed and resuspended in HBSS at $10 \times 10^{6} / \mathrm{mL}$ and kept in the dark at room temperature until use. For flow chamber experiments, THP-1 cells were added to binding buffer at $2 \times 10^{5} / \mathrm{mL}$ and allowed to equilibrate for 20 minutes at $37^{\circ} \mathrm{C}$. Final concentrations of $\mathrm{Ca}^{2+}$ and $\mathrm{Mg}^{2+}$ were $2 \mathrm{mmol} / \mathrm{L}$. In a further set of experiments, THP- 1 cells were used at $2 \times 10^{5} / \mathrm{mL}, 4 \times 10^{5} / \mathrm{mL}$, and $6 \times 10^{5} / \mathrm{mL}$ in the presence or absence of $3: 1$ activated platelets to examine whether the platelet/THP-1 ratio or the number of platelets was the determining factor of augmented THP-1 cell adhesion.

Platelet isolation. Blood was drawn from healthy volunteers by puncture of an antecubital vein with an $18 \mathrm{G}$ needle and freely drained on $0.1 \mathrm{vol}$ citrate $(108 \mathrm{mmol} / \mathrm{L})$. Whole blood was centrifuged at $150 \mathrm{~g}$ for 10 minutes to obtain platelet-rich plasma (PRP), which was diluted in 1:1 vol ACD and centrifuged at $600 \mathrm{~g}$ for 10 minutes. The resulting pellet was resuspended in HBSS and 0.3 vol ACD was added before the final wash at $600 \mathrm{~g}$ for 10 minutes. Platelets were counted and resuspended in HBSS after removing residual $\mathrm{ACD}$ at $300,000 / \mu \mathrm{L}$ and stored at room temperature until use within 3 hours. An aliquot of platelets was diluted to $50,000 / \mu \mathrm{L}$ in binding buffer and activated by the addition of $100 \mu \mathrm{mol} / \mathrm{L}$ TRAP for 10 minutes and then immediatelely added to the THP-1 suspension for perfusion experiments.

FACS analysis of P-selectin expression. Washed platelets $(2.5 \times$ $10^{5} / \mu \mathrm{L}$ ) from 3 different donors were activated with $100 \mu \mathrm{mol} / \mathrm{L}$ TRAP for 10 minutes in the presence of $1 \mu \mathrm{g} / \mathrm{mL} \mathrm{G} 4120$. Samples of resting and activated platelets were fixed at $4^{\circ} \mathrm{C}$ for 2 hours with $1 \%$ paraformaldehyde in Tyrode's buffer. Platelets were washed and resuspended in Tyrode's buffer and labeled for 20 minutes with the FITC-conjugated P-selectin antibody Thromb/6. Expression of Pselectin on the platelet membrane was analyzed using the FACS Calibur (Becton Dickinson) equipped with an argon ion laser at wavelength 488 nm.

Flow chamber perfusion studies. HUVEC on glass coverslips were washed free of media with binding buffer and mounted on the bottom of a parallel plate flow chamber with a chamber height of $0.2 \mathrm{~mm} .{ }^{29}$ Defined shear rates between 100 and $700 \mathrm{~s}^{-1}$ were generated with a precision pump in withdrawal mode (Harvard Instruments, South Natick, MA). The flow chamber was placed on the stage of an inverted epifluorescence microscope (Diaphot; Nikon, Melville, NY) equipped with a $20 \times$ and a $4 \times$ long working distance lens, allowing direct, real time, videomicroscopic observation of interactions between fluorophor labeled platelets and/or monocytes with the endothelial monolayer. Labeling of monocytes and exposure to the fluorescent light did not alter numbers of rolling or adhering cells (data not shown). Blocking antibodies and antagonists were added 20 minutes before the perfusion at the indicated final concentrations to the THP-1 suspension before activated platelets were added. Single passage perfusions with platelets, THP-1 cells, or both were performed for 5 minutes. During this period, 5 video recordings spanning in total 50 seconds were obtained at defined time intervals from 5 different high-power fields of $0.06 \mathrm{~mm}^{2}$ each with a Cohu CCD video camera (COHU Inc, San Diego, CA). Images were read directly into the memory of an attached computer (Apple Computers Inc, Palo Alto, CA) equipped with a Scion LG3 frame grabber (Scion Corp, Frederick, ML) and stored on the hard drive for later off-line analysis of the numbers of rolling cells. The movies were recorded at a set rate of 20 frames per second. After 5 minutes, the coverslips were rinsed with binding buffer for 5 minutes at a shear rate of $400 \mathrm{~s}^{-1}$ and 15 high-power fields were recorded. 
Platelet labeling and superfusion. For direct visualization of platelet/ endothelial cell interactions, washed platelets were incubated with 1 $\mu \mathrm{mol} / \mathrm{L}$ BCECF-AM for 20 minutes at $300,000 / \mu \mathrm{L}$ in HBSS, activated with $100 \mu \mathrm{mol} / \mathrm{L}$ TRAP for 10 minutes, and then diluted to $10,000 / \mu \mathrm{L}$ in binding buffer. For superfusions with reconstituted blood, platelets were resuspended at $10,000 / \mu \mathrm{L}$ in a mixture of packed red blood cells (purchased from the Red Cross Blood Bank, Leuven, Belgium) and binding buffer to obtain a hematocrit of $40 \%$. In these experiments, no monocytes were present. In separate sets of experiments, activated platelets were superfused at $600 / \mu \mathrm{L}$ in binding buffer for 5 minutes, followed by 5 minutes of rinsing. Then, $2 \times 10^{5} \mathrm{THP}-1$ cells $/ \mathrm{mL}$ were superfused and adhesion was quantitated.

Perfusion studies with reconstituted blood and fibrinogen-coated albumin microcapsules. In these experiments, THP-1 cells were resuspended at $2 \times 10^{5} / \mathrm{mL}$ with or without $3: 1$ platelets in reconstituted blood. Packed red blood cells were washed at $150 \mathrm{~g}$ with binding buffer to remove residual platelets before the hematocrit was adjusted to $40 \%$. Alternatively, THP-1 cells were resuspended in binding buffer containing 10,000 fibrinogen-coated albumin microcapsules per microliter before activated platelets were added. These microcapsules have been demonstrated to closely resemble platelets in size distribution and recruitment to forming thrombi. ${ }^{30}$ To exclude the possibility that rheological changes in the presence of corpuscular particles in the perfusate caused the inhibitory effect on THP-1 cell adhesion at higher platelet THP-1 ratios, we chose this approach instead of nonactivated platelets to avoid interference by mildly activated platelets generated during the platelet isolation, because very low concentrations of activated platelets in relation to THP-1 cells in our studies already affected THP-1 adhesion.

Deposition of platelets. Human blood was drawn on $3.82 \%$ citrate and superfused for 5 minutes at $400 \mathrm{~s}^{-1}$ over coverslips coated with 1 $\mathrm{mg} / \mathrm{mL}$ calf skin collagen I. This protocol yielded homogeneous deposition of platelet microaggregates on the coverslip. The coverslips were rinsed until no red blood cells were observed microscopically and were then immediately used for perfusion experiments with $1 \times 10^{5}$ THP-1 cell $/ \mathrm{mL}$ suspensions.

Contribution of shear to formation of platelet/THP-1 complexes. To elucidate whether complex formation between platelets and THP-1 cells would occur in suspension and whether exposure to shear forces during the superfusion in the flow chamber would enhance this complex formation, platelets were labeled with BCECF-AM, activated with 100 $\mu \mathrm{mol} / \mathrm{L}$ TRAP for 10 minutes, and added in a ratio of $3: 1$ to $2 \times 10^{5}$ nonlabeled THP- 1 cells $/ \mathrm{mL}$ binding buffer. The number of THP- 1 cells bearing labeled platelets and the overall number of THP-1 in the cell suspension was assessed microscopically in mixed white and fluorescent light in a Fuchs-Rosenthal counting chamber (Electron Microscopy Sciences, Fort Washington, PA) before and after passage of the flow chamber. The fraction of platelet decorated THP-1 cells deposited on HUVEC after 5 minutes of superfusion and 5 minutes of buffer rinse was also counted. For each of these experiments, at least 100 THP-1 cells on the monolayer were counted in mixed white and fluorescent light and the fraction of platelet bearing THP-1 cells was assessed. Similar experiments were performed in the presence of the P-selectin blocking antibody Thromb/6 $(2.5 \mu \mathrm{g} / \mathrm{mL})$.
Sialidase digestion. HUVEC were overlayed with sialidase at 0.1 $\mathrm{U} / \mathrm{mL}$ and kept in an incubator for 30 minutes. For platelet incubations, the enzyme was added to the platelets after activation to reach a final concentration of $0.1 \mathrm{U} / \mathrm{mL}$ and then diluted greater than 100-fold in THP-1 cell suspension after 30 minutes. THP- 1 cells $\left(10 \times 10^{6} / \mathrm{mL}\right)$ were incubated with $0.4 \mathrm{U} / \mathrm{mL}$ sialidase for 60 minutes and then diluted to $2 \times 10^{5} / \mathrm{mL}$ in binding buffer for perfusion experiments. Cell suspensions were kept in a $37^{\circ} \mathrm{C}$ waterbath during the incubation period and the experiment.

Data analysis and statistical methods. The recorded movies were analyzed off-line with NIH Image 1.61 (developed at the Regional Services Branch of the National Institute of Mental Health, Bethesda, $\mathrm{MD})$. The movies were reduced to every fourth frame for analysis after detecting brightly labeled THP-1 cells. Movies were black-white inverted to facilitate further image processing. These frames were overlayed, with the resulting image depicting rolling cells as series of dark blobs. Rolling cells were defined as cells moving more than their own diameter during the movie, before arresting on the endothelium or leaving the endothelial cells to return back to the speed of the flowing cells. The number of cells in the 5 movies of 1 experiment spanning the full duration of the superfusion was defined as rolling THP-1 cells per 50 seconds. Adhering cells were recorded on 15 high-power fields of $0.06 \mathrm{~mm}^{2}$ each after 5 minutes of buffer rinse and were saved as a stack of single frames on the hard drive of the attached computer. Because after this time rolling cells were no longer observed, cells that were still present on the endothelium were defined as adhering THP- 1 cells $/ 0.9$ $\mathrm{mm}^{2}$. Data were processed in InStat 2.03, GraphPad Software Inc (San Diego, CA). For comparison between groups, a Kruskal-Wallis nonparametric ANOVA test, followed by a Dunn's multiple comparison test, was performed. To assess differences in platelet decoration of THP-1 cells, a $\chi^{2}$ test was performed on all cells that were counted under the different conditions, and the individual fractions of platelet bearing THP-1 cells were then compared by Fisher's exact test. A $P$ value less than .05 was considered significant. Data are reported as the mean \pm standard error of the mean (SEM).

\section{RESULTS}

Shear dependence of THP-1 adhesion to HUVEC. Resting HUVEC did not support rolling and adhesion of THP-1 cells at shear rates greater than $400 \mathrm{~s}^{-1}$. Activation of HUVEC with PMA led to a significant increase of rolling and adhesion at shear rates of 300 and $200 \mathrm{~s}^{-1}$ (Table 1). Because $400 \mathrm{~s}^{-1}$ appeared to be a threshold shear rate for monocyte endothelial cell interaction in our flow chamber system, the following studies were performed at this shear rate and after activation of HUVEC monolayers with PMA to examine if activated platelets would enhance THP-1/endothelial cell interactions.

$P$-selectin expression on activated platelets. TRAP activation of washed platelets induced a significant shift of mean fluorescence values $(9.2 \pm 0.8 v 39 \pm 5.8, \mathrm{n}=3, P<.05)$, indicating pronounced expression of $\mathrm{P}$-selectin on the platelet membrane.

Table 1. Activation of HUVEC With $100 \mu \mathrm{mol} / \mathrm{L}$ PMA for 4 Hours Increases THP-1 Rolling and Adhesion Only at Shear Rates Less Than $400 \mathrm{~s}^{-1}(\mathrm{n}=\mathbf{3 / 6})$

\begin{tabular}{|c|c|c|c|c|c|}
\hline & \multicolumn{4}{|c|}{ Shear Rate } & \\
\hline & $500 \mathrm{~s}^{-1}$ & $400 \mathrm{~s}^{-1}$ & $300 \mathrm{~s}^{-1}$ & $200 s^{-1}$ & \\
\hline Resting EC & $0 \pm 0$ & $1 \pm 0$ & $4.3 \pm 1.7$ & $7.7 \pm 3.1$ & Rolling THP-1 cells/50 s \\
\hline PMA EC & $0.2 \pm 0.4$ & $1.2 \pm 0.9$ & $9.3 \pm 3.2^{*}$ & $15 \pm 6^{*}$ & \\
\hline Resting EC & $0 \pm 0$ & $72 \pm 16$ & $110 \pm 50$ & $180 \pm 35$ & Adhering THP-1 cells $/ 0.9 \mathrm{~mm}^{2}$ \\
\hline PMA EC & $2.2 \pm 2.6$ & $65 \pm 13$ & $180 \pm 43^{*}$ & $430 \pm 160 *$ & \\
\hline
\end{tabular}

${ }^{*} P<.05 v$ resting EC. 
Activated platelets augment THP-1 rolling and adhesion. The addition of 1 to 50 TRAP-activated platelets per THP- 1 cell to the superfusions at $400 \mathrm{~s}^{-1}$ on PMA-activated HUVEC showed a steep, bell-shaped dose-response curve at very low platelet/leukocyte ratios, with a peak at 3 platelets/THP-1 cell and an inhibitory effect compared with the control experiments starting at a ratio of 10 activated platelets/THP-1. At 50 platelets per leukocyte, rolling and adhesion were virtually abolished (Fig 1).

The addition of 3 activated platelets per THP-1 cell caused a marked shift of the adhesive interactions towards higher shear resistance. At $300 \mathrm{~s}^{-1}$, the addition of platelets to the suspension still increased margination of THP-1 cells from $9.3 \pm 5.3$ to $37 \pm 3.7$ rolling monocytes $/ 50$ seconds at $300 \mathrm{~s}^{-1}(P<.01, \mathrm{n}=$ $6)$. These increases in dynamic interactions resulted in a corresponding increase of firmly adhering THP-1 cells. The threshold shear rate $\left(400 \mathrm{~s}^{-1}\right)$ yielded $184 \pm 55$ versus $65 \pm 13$ adhering THP-1 cells per $0.9 \mathrm{~mm}^{2}(P<.01, \mathrm{n}=6$; Fig 2$)$. THP-1 cells $\left(2 \times 10^{5}\right)$ were superfused in reconstituted blood to titrate a similar threshold shear rate as for the experiments in buffer (data not shown). At a shear force of 5 dyn, a similar augmentation of THP-1 rolling and adhesion was observed:
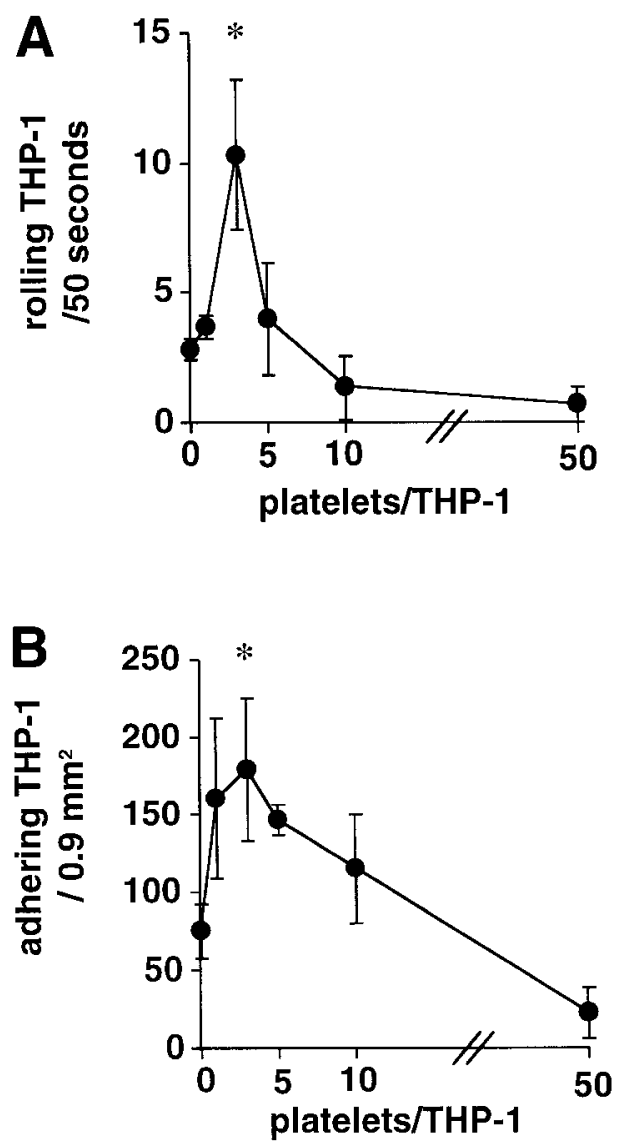

Fig 1. Activated platelets augment THP-1 rolling and adhesion. Addition of 1 to 50 TRAP-activated platelets per THP-1 cell showed a steep bell-shaped dose-response curve of monocyte rolling $(A)$ and adhesion (B) on PMA-activated HUVEC, with a narrow peak at 3 platelets per monocyte. Inhibition of monocyte margination was observed at ratios $=10$ platelets per monocyte $\left(n=4,{ }^{*} P<.01 \mathrm{v}\right.$ no platelet control).
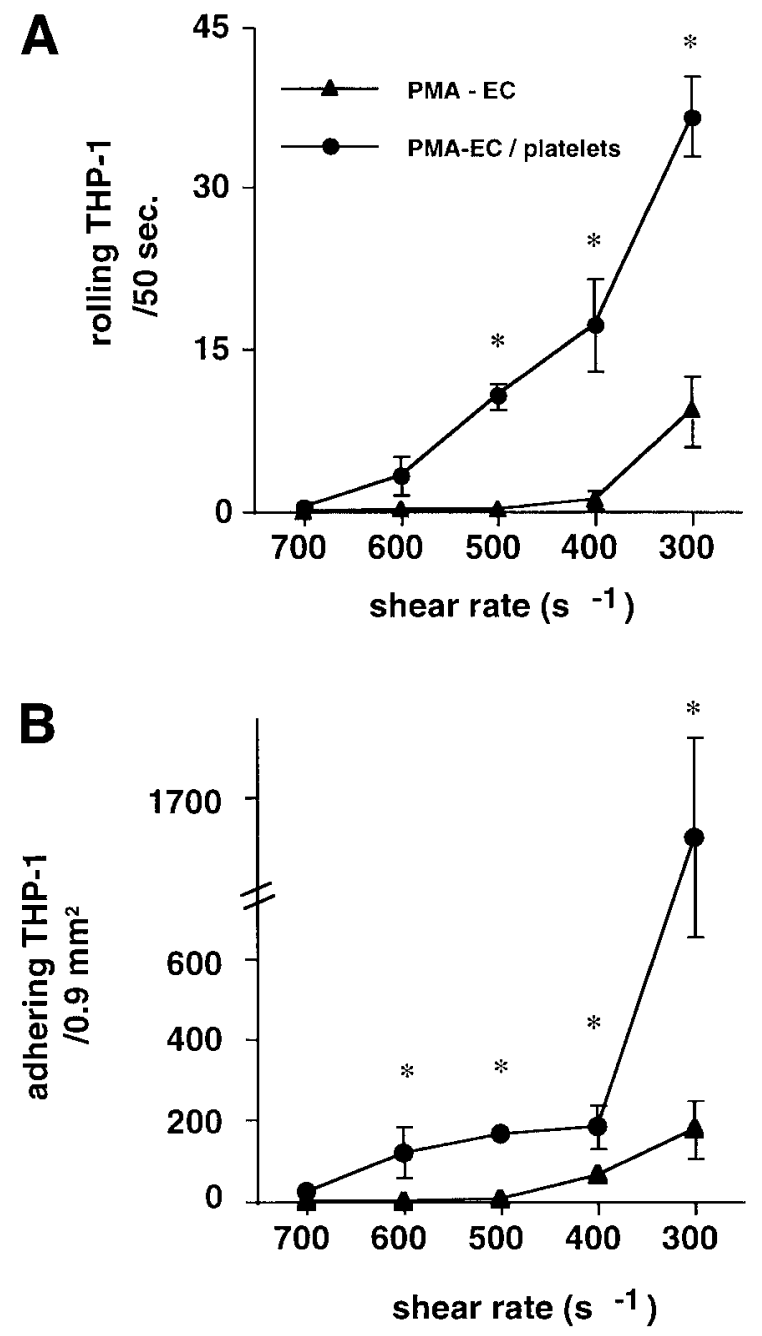

Fig 2. Addition of 3:1 platelets to the THP-1 suspension causes a left shift in the shear response. THP-1 cell rolling and adhesion to PMA-activated HUVEC (A) was only detectable at shear rates less than $400 \mathrm{~s}^{-1}$. The addition of 3 TRAP-activated platelets per THP-1 cell (O) supported dynamic and firm interactions up to $600 \mathrm{~s}^{-1}$. Rolling (A) and adhesion (B) of THP-1 cells similarly increased with the addition of activated platelets to the suspension ( $n=6$, for each condition, ${ }^{*} P<.01 v$ PMA-activated HUVEC in the absence of platelets).

$1.4 \pm 0.8$ THP- 1 cells rolled in the absence of platelets. This rolling was augmented to $6.2 \pm 1.3$ rolling THP-1/50 seconds, when 3:1 TRAP-activated platelets were added to the suspension $(\mathrm{n}=5, P<.01)$. Adhesion was likewise increased from $14.8 \pm 7.5$ to $50.4 \pm 10$ adhering THP- 1 cells per $0.9 \mathrm{~mm}^{2}(\mathrm{n}=$ $5, P<.01)$.

When the THP-1 cell count in binding buffer was increased stepwise from $2 \times 10^{5}$ to $4 \times 10^{5}$ and $6 \times 10^{5} / \mathrm{mL}$, while the ratio of activated platelets was kept at $3: 1$, there was an increase in basal rolling and adhesion as a function of THP-1 cell number, even in the absence of platelets. However, the significant augmentation of THP-1 cell rolling and adhesion to HUVEC by activated platelets was conserved (Fig 3). To rule out that rheological changes were responsible for the inhibitory effect of higher numbers of platelets per THP-1 cell, fibrinogencoated albumin microparticles were included in the superfusion 

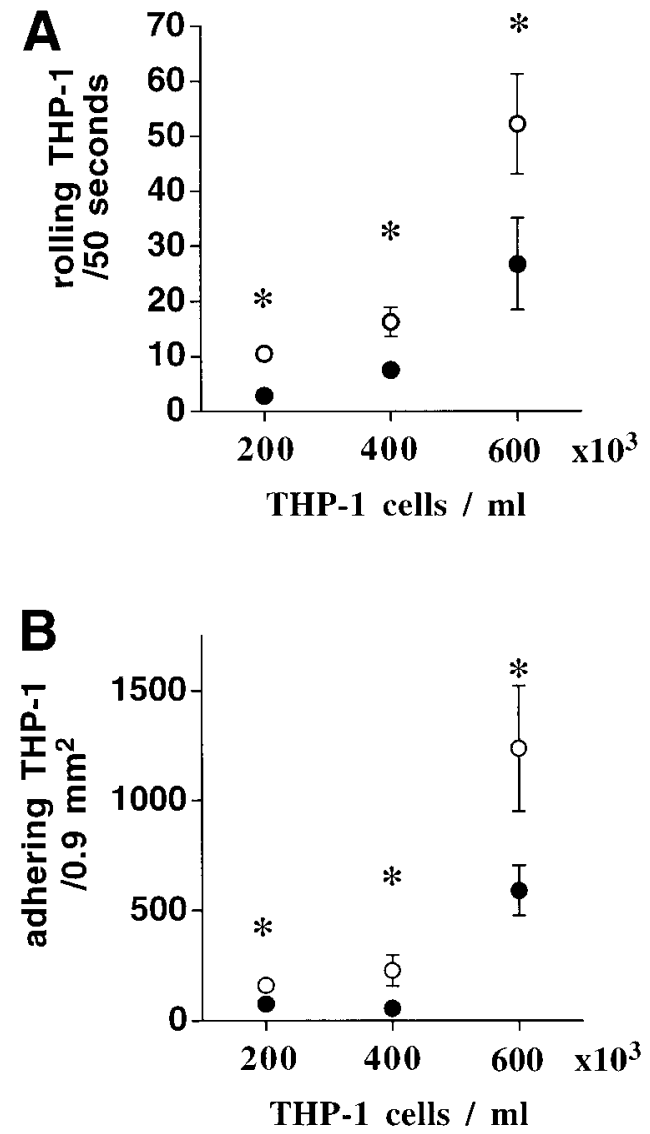

Fig 3. When THP-1 cell numbers were stepwise increased from $2 \times 10^{5}$ to $4 \times 10^{5}$ and $6 \times 10^{5}$, basal rolling and adhesion increased progressively (O). The addition of 3:1 activated platelets $(O)$ further augmented THP-1 cell rolling (A) and adhesion (B) irrespective of absolute THP-1 cell number $\left(n=4,{ }^{*} P<.01\right)$.

to mimick the presence of excess resting platelets. The augmentation of THP-1 adhesion by activated platelets was conserved, even when 10,000 microcapsules per microliter (a 20-fold excess in comparison to the ratio $3: 1$ ) were present during the superfusion $(1.8 \pm 0.8 v 11 \pm 3.3$ rolling THP-1/50 seconds and $63 \pm 6.5 v 191 \pm 64$ adhering THP-1/0.9 $\mathrm{mm}^{2}, \mathrm{n}=4, P<.05$, in the absence or presence of activated platelets).

THP-1 rolling on deposited platelets. When THP-1 cells were superfused at $400 \mathrm{~s}^{-1}$ over immobilized platelets, significant rolling occurred. Upon addition of increasing numbers of activated platelets to the superfusate, a progressive inhibition of THP-1 cell rolling was observed, with an $\mathrm{IC}_{50}$ of 940 platelets/ $\mu \mathrm{L}$, corresponding to approximately 10 platelets per THP- 1 cell. The addition of nonactivated platelets also caused inhibition of THP-1 rolling, with an $\mathrm{IC}_{50}$ of 22,300 platelets $/ \mu \mathrm{L}$. THP- 1 cell rolling on deposited platelets was also dose-dependently inhibited by the P-selectin blocking antibody Thromb/6, whereas control antibodies against CD34 or platelet GPIb did not affect THP-1 rolling (Fig 4). Because $2.5 \mu \mathrm{g} / \mathrm{mL}$ Thromb/6 virtually abolished leukocyte rolling on deposited, activated platelets, this concentration of blocking antibody was used for all further experiments. Therefore, the inhibition of THP-1 rolling over coated platelets by high resting platelet numbers seems to be due to mild activation and P-selectin expression on a subset of platelets as a consequence of the isolation procedure.

Interaction of activated platelets with HUVEC. Whether the platelet/THP-1 cell interactions that augmented sheardependent monocyte margination occurred in suspension or with deposited platelets on the HUVEC surface was studied as follows. Platelet adhesion on HUVEC was directly determined by epifluorescence microscopy. Ten thousand TRAP-activated platelets per microliter, perfused at $400 \mathrm{~s}^{-1}$, did not interact with PMA-activated HUVEC when suspended in binding buffer: $3.7 \pm 0.7$ platelets rolled within 50 seconds and $34 \pm 7.4$ platelets arrested on $0.15 \mathrm{~mm}^{2}$ of PMA-activated HUVEC. After suspension of activated platelets in reconstituted blood, $37 \pm 1.9$ translocating platelets per 50 seconds and 1,103 \pm 113 adhering platelets $/ 0.15 \mathrm{~mm}^{2}$ (Fig $5, \mathrm{n}=4 ; P<.001$ ) were counted. In binding buffer in which activated platelets supported THP-1 cell delivery to HUVEC, ie, at 600 platelets $/ \mu \mathrm{L}$ and $200 \mathrm{THP}-1$ cells $/ \mu \mathrm{L}$, direct interactions of individual platelets with HUVEC were virtually absent (data not shown).

To further support the conclusion that platelet deposition and subsequent THP-1 adhesion was not the mechanism of platelet assistance to monocyte adhesion, platelet perfusion and THP-1 perfusion were separated. A prior superfusion of activated platelets at $600 / \mu \mathrm{L}$ did not yield an increase in subsequent monocyte adhesion $\left(72 \pm 2.9 v 76 \pm 8.8 \mathrm{THP}-1\right.$ cells $/ 0.9 \mathrm{~mm}^{2}$, $\mathrm{n}=4, P=$ not significant), indicating that the increased THP-1 adhesion in the presence of platelets was not due to adhesion of THP-1 to previously deposited platelets.

Activated platelets and THP-1 cells form complexes under shear conditions. Most of the monocytoid cells had 1 or 2 platelets attached. THP-1 cells decorated with more than 3

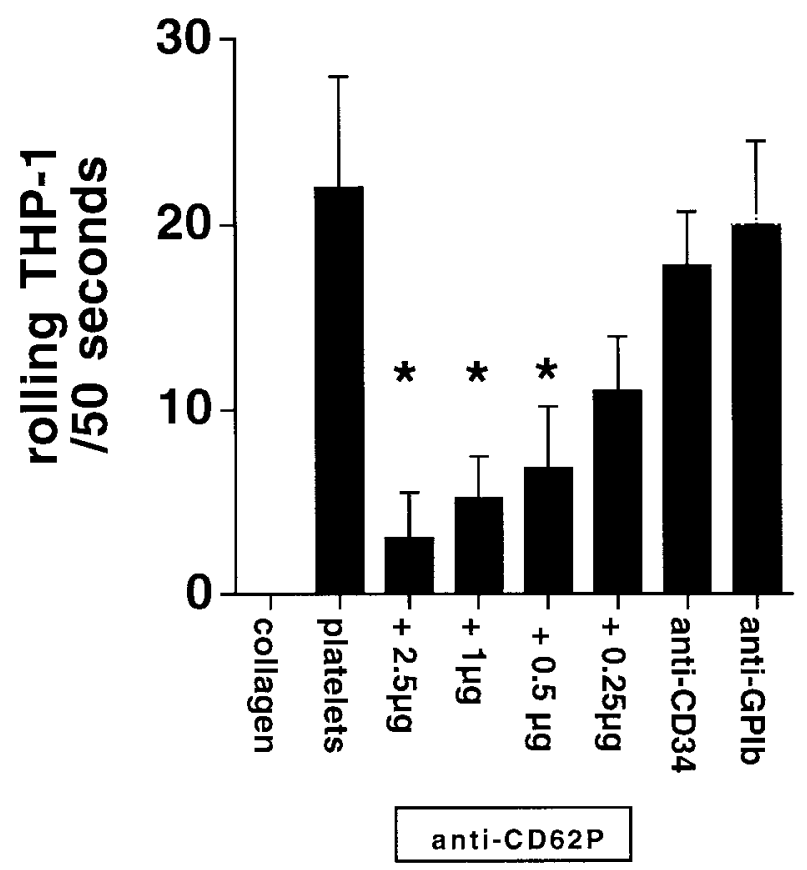

Fig 4. THP-1 cells rolled on deposited platelets in a P-selectindependent fashion (anti-CD62P). There was no interaction in the absence of platelets on the coverslip (collagen). Anti-CD34 and anti-GPIb antibodies did not interfere with rolling ( $n=4, * P<.05 v$ platelets). 
A

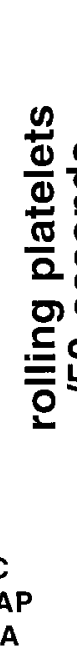

+ TRAP

+ PMA
40

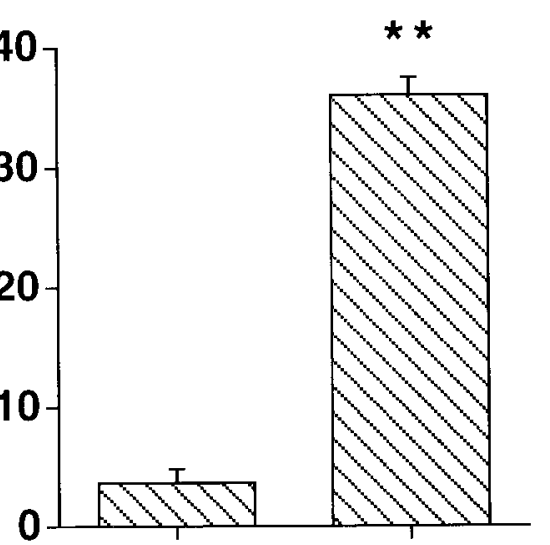

PRBC
B

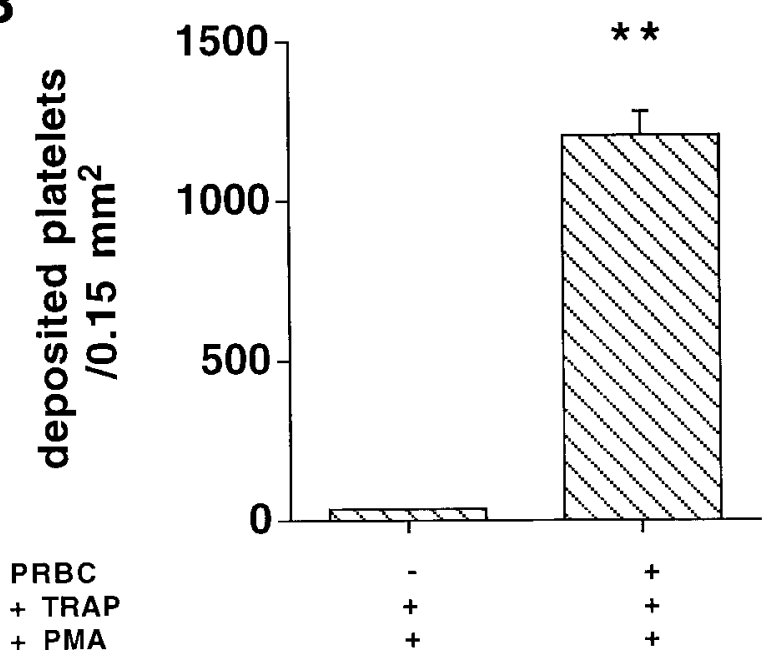

Fig 5. Rolling and adhesion to activated endothelial cells of 10,000 platelets $/ \mu \mathrm{L}$ were only observed in the presence of packed red blood cells (PRBC) but not in binding buffer $(n=4, * * P<.001 v-P R B C)$.

platelets were very rare. Complexes of several THP-1 cells bridged by platelets were only rarely observed and not entered in the analysis. After passage of the flow chamber, the THP-1 number in the effluent was $123,000 \pm 1,600 / \mathrm{mL}$ in the absence of platelets and 92,000 $\pm 16,000(\mathrm{n}=4)$ when $3: 1$ activated platelets were present. Thus, $38 \%$ and $54 \%$ of the THP-1 cells were trapped on the HUVEC monolayer. When labeled platelets were activated and coperfused with nonlabeled THP-1 cells, 160 of 635 ( $\mathrm{n}=5$ experiments) counted THP-1 cells entering the flow chamber were decorated with platelets. The number of THP-1 cells that were decorated with platelets in the effluent was significantly higher (318 of 764, $\mathrm{n}=5, P<.001$ ). Moreover, THP-1 cells recruited to the monolayer also were preferentially decorated with platelets. Upon addition of the P-selectin blocking antibody, the percentage of plateletdecorated THP-1 cells in the pre-perfusion suspension was reduced as was the recruitment of these complexes to the HUVEC and the increase of THP-1 cell decoration in the effluent (Table 2 and Fig 6).

$L$-selectin and P-selectin mediate rolling of leukocyte/platelet complexes. The rolling of labeled THP-1 cells perfused over PMA-activated HUVEC in the absence of activated platelets was inhibited by $64 \%$ after the addition of $2.5 \mu \mathrm{g} / \mathrm{mL}$ of the L-selectin blocking antibody to the superfused THP-1 cells. In the presence of 3 activated platelets $(600 / \mu \mathrm{L})$ per THP- 1 cell $(200 / \mu \mathrm{L})$, the inhibition of the increased rolling by this antibody was $60 \%$. The anti-P-selectin antibody did not block rolling in the absence of platelets, but blocked $40 \%$ of the rolling after platelets were added. Both antibodies together blocked $86 \%$ of the rolling observed in the presence of platelets, reducing the number of rolling monocytes to control levels after L-selectin blockade $(P<.01, \mathrm{n}=4)$. Control antibody against CD34, matched for isotype, did not block rolling or adhesion in the presence or absence of platelets. The anti-GP IIb/IIIa antibody inhibited rolling (Fig 7).

Role of GPIb and GPIIb/IIIa for firm adhesion of platelet/ THP-1-complexes. Blockade of the GPIb pathway caused a trend (not significant) towards reduced rolling of THP-1 cells in the presence of platelets. Firm adhesion was significantly reduced by $40 \%(P<.05, \mathrm{n}=4)$. On the other hand, blocking of GPIIb/IIIa did not reduce monocyte adhesion in the presence of platelets (Fig 7).

Sialidase treatment of HUVEC and THP-1 abolishes rolling of platelet/THP-1 complexes. Treatment of platelets with 0.1 $\mathrm{U} / \mathrm{mL}$ sialidase for 30 minutes did not result in an inhibition of platelet-assisted monocyte adhesion. When HUVEC or THP-1 cells were incubated with sialidase, the numbers of rolling and adhering THP-1 cells in the presence of 3:1 activated platelets at $400 \mathrm{~s}^{-1}$ were reduced to the level found in the absence of activated platelets (Fig 8).

\section{DISCUSSION}

The primary finding of the present study is that activated platelets augment adhesion of monocytoid cells to cultured activated HUVEC in a flow chamber system under moderate shear forces. Adhesion of THP-1 cells alone was prevented by shear forces resembling those found in arterial vessels that are affected by atherosclerotic lesion development in vivo. However, the addition of very small numbers of activated platelets

Table 2. Interactions of Platelets With THP-1 Cells Are Increased by Passage Through the Flow Chamber

\begin{tabular}{lcccccccc}
\hline & \multicolumn{2}{c}{ Prechamber } & & \multicolumn{2}{c}{ Coverslip } & & \multicolumn{2}{c}{ Postchamber } \\
\cline { 2 - 3 } & Control & Thromb/6 & & Control & Thromb/6 & & Control & Thromb/6 \\
\hline THP-1 & 475 & 413 & & 452 & 455 & & 446 & 388 \\
THP-1 + platelet & $160^{*}$ & $70 \dagger$ & & 472 & $29 \dagger$ & & $318 \ddagger$ & $70 \dagger$ \\
Total & 635 & 483 & & 924 & 464 & & 764 & 458 \\
\hline
\end{tabular}

Recruitment of platelet-decorated THP-1 cells to HUVEC is favored over platelet-free THP-1 cells. P-selectin monoclonal antibodies inhibit platelet/THP-1 interaction in suspension in response to shear stress as well as adhesion of THP-1/platelet complexes to HUVEC. Data represent individual cell counts from at least 5 independent experiments.

${ }^{*} P<.0001$ prechamber $v$ postchamber and coverslip.

$\dagger P<.001$ Thromb/6 $v$ control.

$\ddagger P<.001 v$ coverslip. 

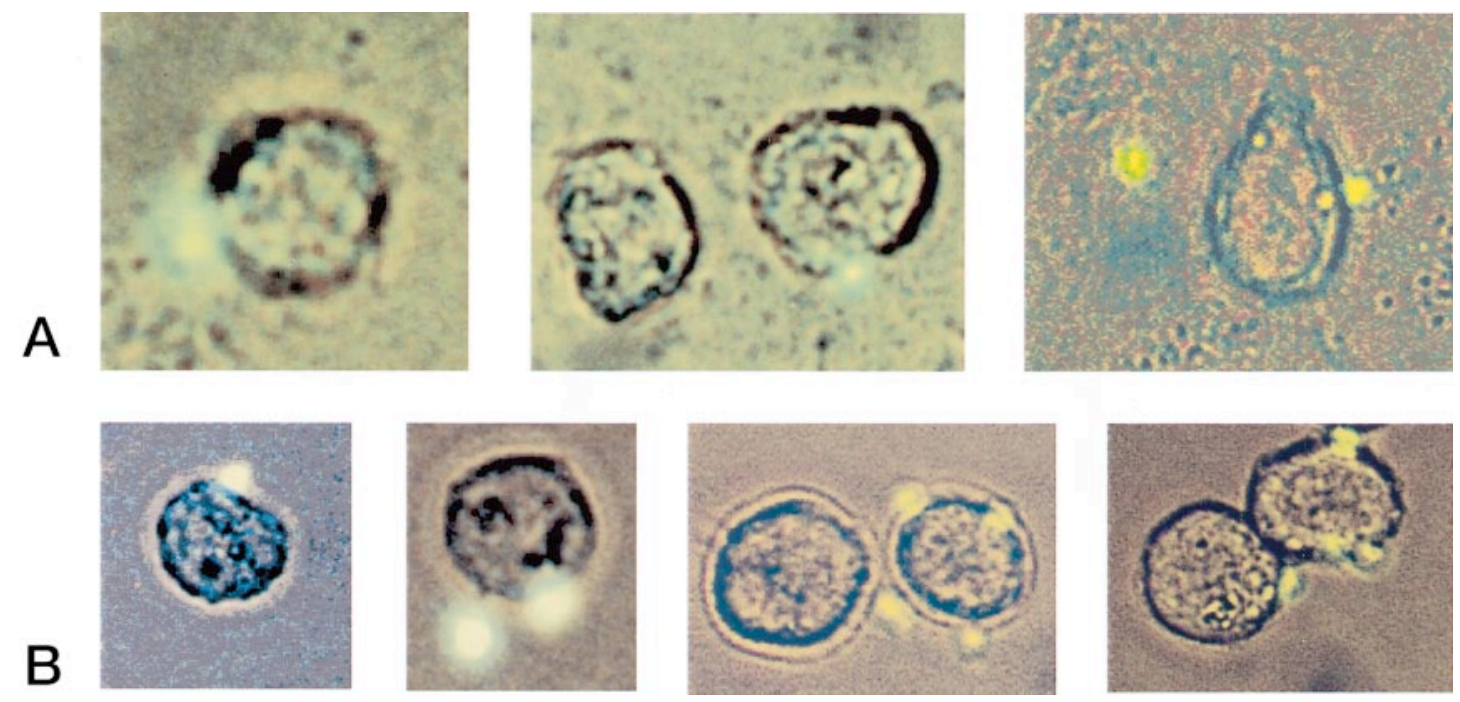

Fig 6. Visualization of platelet/THP-1 complexes. Fluorescently labeled activated platelets were added to the suspension of nonlabeled THP-1 cells in a ratio of 3:1. Complex formation between platelets and THP-1 cells was assessed by combined light and fluorescence microscopy. The panels in row (A) depict micrographs of THP-1/platelet complexes adhering to the endothelial monolayer (40×). Row (B) shows typical examples of sparsely decorated THP-1 cells in the suspension after passage through the flow chamber $(40 \times)$.

enabled interactions between THP-1 and endothelial cells at higher shear rates as a consequence of decoration of the monocytoid cells with platelets in suspension. Platelet-assisted THP-1 delivery to confluent endothelial layers was observed at shear rates of up to $600 \mathrm{~s}^{-1}$. Thus, activated platelets can assist monocytoid cell adhesion to endothelial cells at shear forces that preclude direct monocyte adhesion.

A steep bell-shaped dose-response curve was observed, demonstrating platelet-supported THP-1 adhesion in a narrow range of platelet/THP-1 ratios. Inhibition of THP-1 adhesion in the presence of excess platelets suggested that the interaction between platelets and THP- 1 cells in suspension was mediated at least partially by the same adhesion molecule as the interaction of the complex with the endothelial cell. The significant augmentation of THP-1 adhesion with increasing numbers of THP- 1 cells but at a constant ratio of $3: 1$ activated platelets indicated that the platelet/THP-1 ratio was the critical parameter, not the absolute platelet number, suggesting that the observed platelet-mediated augmentation of THP-1 adhesion could occur across the whole physiological range of monocyte counts in vivo, provided that circulating activated platelets are present. Counts of activated platelets can be as high as $10 \%$ after acute coronary syndromes and interventional revascularization or thrombolysis. ${ }^{14}$ Lower fractions of activated platelets have been reported in the earlier stages of the disease process. ${ }^{15,18}$ The presence of truly resting platelets does not interfere with the observed effect of low numbers of activated platelets, because in the experiments with albumin microcapsules, a similar increase of rolling and adhesion was observed when 3 TRAP-activated platelets were added in the presence or absence of these artificial platelets. This rules out that the inhibition of THP-1 rolling and adhesion in the presence of greater than 10 activated platelets was caused by changes in the numbers of cells in the perfusate or by changes in viscosity.

Kuijper et al ${ }^{10}$ have reported neutrophil adhesion to platelets that had been previously deposited on extracellular matrix between HUVEC strained by shear stress. In this system, leukocyte adhesion occurred preferentially to platelets instead of endothelial cells. ${ }^{10}$ However, this study did not include platelets in the superfusate.

To further characterize the interaction between the 3 cell types, the THP-1/endothelial cell, platelet/endothelial cell, and THP-1/platelet interactions were separated. Platelet adhesion to activated HUVEC required a hemorheological cell distribution as in blood, in which the presence of red blood cells drives platelets into the periphery of the perfused lumen, thus increasing the density of platelets in the immediate vicinity of the endothelial lining. ${ }^{31}$ The classical finding that platelet/matrix interaction requires red blood cells was extended to the adhesion of activated platelets to activated endothelium by adding labeled platelets to reconstituted blood, which immediately resulted in ample translocation and adhesion of individual activated platelets to activated endothelial cells. When THP-1 cells were resuspended in reconstituted blood, the addition of 3:1 activated platelets yielded similar increases in rolling and adhesion as in the buffer system. However, under these conditions, a contribution of independently deposited platelets to THP-1 adhesion cannot be ruled out. Therefore, all other experiments were performed in buffer, in which the rheological parameters did not allow platelets to adhere by themselves.

Monocytes are known to roll on and adhere to predeposited platelets. ${ }^{9}$ Antibody studies showed that THP-1 adhesion to deposited platelets was primarily mediated by P-selectin, as has been reported by several groups. ${ }^{9,21,32}$ However, the presence of activated platelets in the suspension inhibited monocyte adhesion, providing additional evidence for an interaction between THP-1 cells and platelets in suspension and suggesting Pselectin to be one of the candidate molecules involved in complex formation between circulating platelets and monocytes.

The rate of complex formation in the THP-1/platelet solution before perfusion through the flow chamber was rather low at 


\section{A}
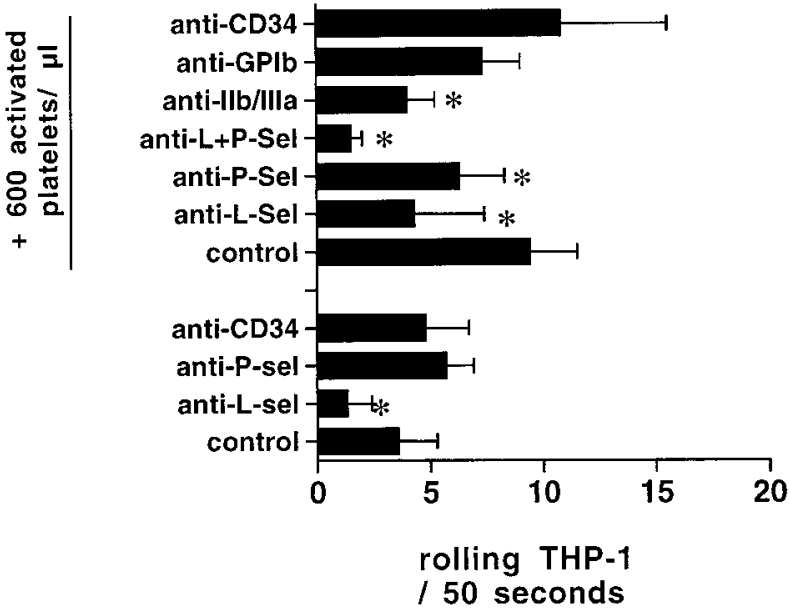

B
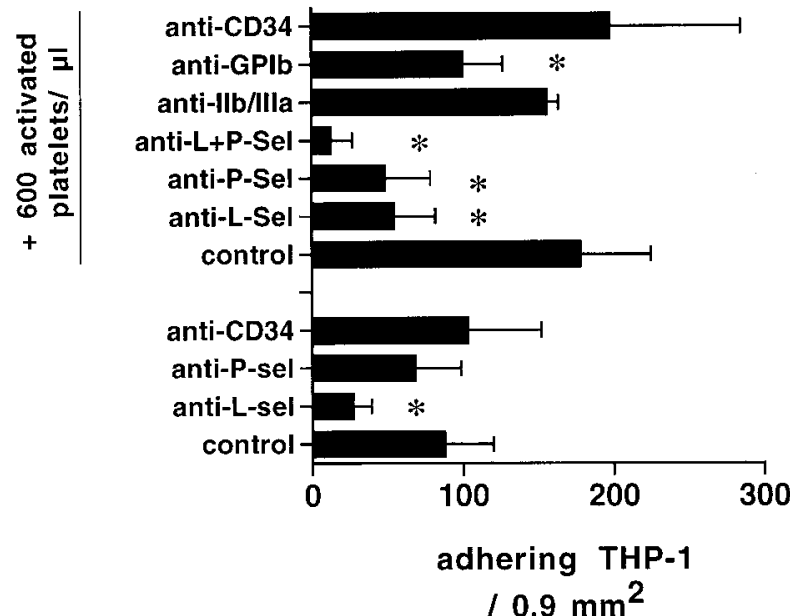

Fig 7. Rolling of THP-1 cells on PMA-activated HUVEC was to a large extent mediated by L-selectin. P-selectin inhibition did not yield a blocking effect. After the addition of activated platelets (ratio 3:1), Land P-selectin blocking resulted in an inhibition of rolling and a concomitant reduction of adhering monocytes. GPIlb/Illa blockade resulted in reduced rolling, whereas GPIb inhibition reduced adhesion of complexes without affecting rolling of THP-1 cells in the presence of platelets ( $n=4$ for each condition, ${ }^{*} P<.05$ ).

approximately $25 \%$, whereas passage through the chamber significantly increased decoration of THP-1 cells with platelets, confirming the impact of shear on the association of activated platelets with leukocytes as reported before. ${ }^{33}$ The P-selectin blocking antibody decreased the percentage of plateletdecorated THP-1 cells in the cell suspension before passage through the chamber and prevented the shear-induced increase in THP-1 cell decoration after passage through the flow chamber. Importantly, P-selectin inhibition virtually abolished the preference for the recruitment of decorated THP-1 cells to the HUVEC monolayer. This finding is in agreement with and confirms previous findings, ${ }^{32,34,35}$ suggesting that engagement of selectins with their ligands requires threshold shear forces. However, it cannot be excluded that monocytes binding platelets through $\mathrm{P}$-selectin may become activated and express adhesion molecules that may mediate adhesion at higher shear rates. ${ }^{36}$ P-selectin engagement in flow mediated delivery of THP-1 cells by activated platelets to the endothelium, as evidenced by reduced deposition of these complexes after P-selectin inhibition. P-selectin contributes to the decoration of monocytes with platelets as well as to their delivery to endothelial layers.

Rolling of THP-1 cells on HUVEC in the absence of platelets was, as expected, largely mediated by L-selectin, ${ }^{37}$ with no effect of P-selectin blockade. However, in the presence of 3 activated platelets per THP-1 cell, P-selectin accounted for $40 \%$ of the rolling of the complexes. Because the total number of rolling cells increased in the presence of platelets, $60 \%$ inhibition of rolling by anti-L-selectin antibodies indicated that the decoration of THP-1 cells with platelets also favored direct

A
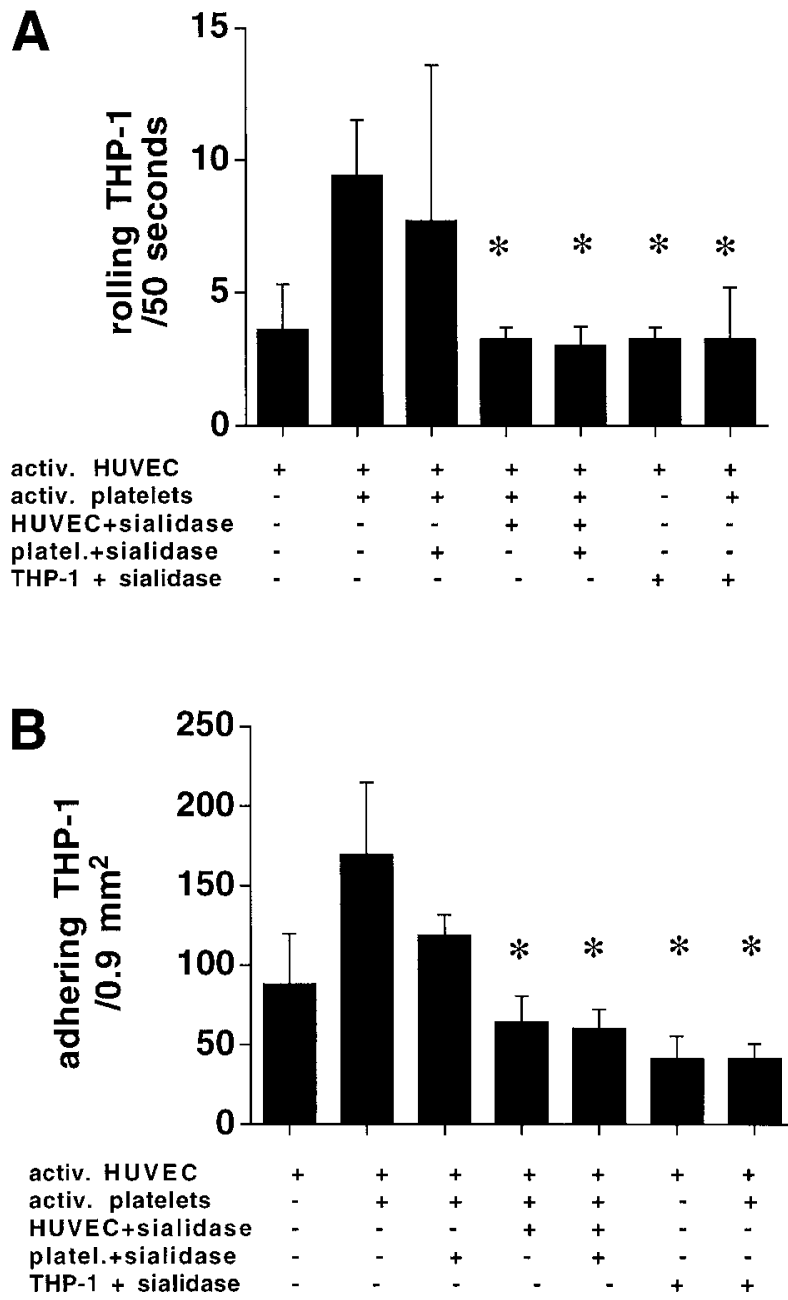

Fig 8. HUVEC and THP-1 treatment with sialidase abolished the platelet-mediated (ratio 3:1) augmentation of rolling and subsequent adhesion of THP-1 cells at $400 \mathrm{~s}^{-1}$. Sialidase treatment of platelets had no effect. Combined sialidase digestion of HUVEC and platelets did not further reduce THP-1/endothelial cell interaction in the presence of activated platelets $\left(n=4,{ }^{*} P<.05\right)$. 
THP-1 cell interactions with the endothelium. Combination of both antibodies nearly abolished rolling and adhesion, indicating that the margination of THP-1 cells by platelets allowed the engagement of L-selectin with its ligands. These findings also demonstrate that the flow chamber model used for these studies very closely resembles leukocyte endothelial cell interactions in vivo, because the disruption of the initial selectin mediated tethering and rolling also abolished firm adhesion of leukocytes, as postulated in the multistep model of leukocyte adhesion. ${ }^{38}$

Because P-selectin is expressed on activated platelets as well as on endothelial cells and the ligand PSGL-1 is present on leukocytes and endothelium, THP-1, platelets, or HUVEC were exposed to neuraminidase to eliminate the respective selectin ligands. Treatment of platelets with the enzyme did not inhibit the augmented THP-1/HUVEC interactions, whereas digestion of sialyl sugars on THP-1 or HUVEC reduced THP-1 adhesion in the presence of platelets to the level found in the absence of activated platelets. These results clearly show that platelet P-selectin in a first step engages sialyl sugars on THP-1 cells to form complexes. In a second step, P-selectin on the platelet travelling with the THP-1 engages sialyl sugars present on the endothelial cell. Removal of either receptors on THP-1 or endothelial cells completely disrupts this triangular interaction.

The inhibitory effect of the GPIb blocking antibody on firm THP-1 cell adhesion in the presence of platelets indicates a role for von Willebrand factor anchored on endothelial cells in mediating monocyte/platelet adhesion to endothelial cells. Another putative ligand for platelet GPIb is intercellular adhesion molecule-1 (ICAM-1), expressed after activation of endothelial cells. ${ }^{39}$ Because GPIb inhibition did not affect THP-1 interactions with deposited platelets, the reduced adhesion in the presence of the blocking antibody suggests an involvement of platelets in firm THP-1 cell adhesion to HUVEC via this pathway. GPIIb/IIIa, which has been suggested to be the only platelet membrane receptor mediating platelet/HUVEC interactions in a static adhesion assay, ${ }^{39}$ does not seem to play a role in the phenomenon under investigation here. As for the increased contribution of L-selectin to rolling in the presence of platelets, it seems likely that monocyte adhesion molecules ${ }^{37}$ and their ligands mediate monocyte/endothelial cell interactions after platelet decoration has led to a P-selectin-mediated margination of the complex.

In conclusion, our data support the hypothesis that activated platelets assist monocyte adhesion to endothelial cells at shear rates that do not allow monocytes by themselves to adhere to activated endothelium. The interaction of platelets with monocytes occurs in the circulation; it is mediated by platelet $\mathrm{P}$-selectin and dependent on ambient shear forces. The margination of platelet decorated monocytes occurs through P-selectin, presented by the platelets, but also augments direct monocyte/ endothelial cell interaction. These findings suggest that circulating activated platelets, as found in hypercholesterolemia in humans, play a role in margination, adhesion, and extravasation of monocytes at sites where shear forces would preclude monocyte/endothelial cell interaction.

\section{ACKNOWLEDGMENT}

Fibrinogen-coated albumin microcapsules were a generous gift from Dr Marcel Levi (Academisch Medisch Centrum, Amsterdam, The
Netherlands). The authors are grateful to Erik Spaepen for excellent technical assistance.

\section{REFERENCES}

1. van Zanten H, de Graaf S, Slootweg PJ, Heijnen HFG: Increased platelet deposition on atherosclerotic coronary arteries. J Clin Invest 93:615, 1994

2. Ross R: The pathogenesis of atherosclerosis: A perspective for the 1990s. Nature 362:801, 1993

3. Ip JH, Fuster V, Badimon L, Badimon J, Taubman MB, Chesebro $\mathrm{JH}$ : Syndromes of accelerated atherosclerosis: Role of vascular injury and smooth muscle cell proliferation. J Am Coll Cardiol 15:1667, 1990

4. Holvoet P, Collen D: Thrombosis and atherosclerosis. Curr Opin Lipidol 8:320, 1997

5. Zimmermann GA, McIntyre TM, Prescott SM: Adhesion and signaling in vascular cell-cell interactions. J Clin Invest 98:1699, 1996

6. Diacovo TG, Puri KD, Warnock RA, Springer TA, von Andrian UH: Platelet mediated lymphocyte delivery to high endothelial venules. Science 273:252, 1996

7. Frenette PS, Johnson RC, Hynes RO, Wagner DD: Platelets roll on stimulated endothelium in vivo: An interaction mediated by endothelial P-selectin. Proc Natl Acad Sci USA 92:7450, 1995

8. Kuijper P, Gallardo Torres HI, Lammers J-WJ, Sixma JJ, Koendermann L, Zwaginga JJ: Platelet and fibrin deposition at the damaged vessel wall: Cooperative substrates for neutrophil adhesion under flow conditions. Blood 89:166, 1997

9. Diacovo TG, Roth SJ, Buccola JM, Bainton DF, Springer TA: Neutrophil rolling, arrest, and transmigration across activated, surface adherent platelets via sequential action of P-selectin and the beta 2-integrin CD 11b/CD18. Blood 88:146, 1997

10. Kuijper P, Gallardo Torres H, van der Linden JAM, Lammers J-WJ, Sixma JJ, Koendermann L, Zwaginga JJ: Platelet-dependent primary hemostasis promotes selectin and integrin-mediated neutrophil adhesion to damaged endothelium under flow conditions. Blood 87:3271, 1996

11. Wolf A, Zalpour C, Theilmeier G, Wang BY, Ma A, Anderson B, Tsao PS, Cooke JP: Dietary L-arginine supplementation normalizes platelet aggregation in hypercholesterolemic humans. J Am Coll Cardiol 29:479, 1997

12. Tsao PS, Theilmeier G, Singer AH, Leung LL, Cooke JP: Increased platelet aggregation in hypercholesterolemic rabbits is reduced by dietary L-arginine. Arterioscler Thromb Vasc Biol 14:1529, 1994

13. Theilmeier G, Chan JR, Zalpour C, Anderson B, Wang BY, Wolf A, Tsao PS, Cooke JP: Adhesiveness of mononuclear cells is increased in hypercholesterolemic humans and reduced by the NO precursor. Arterioscler Thromb Vasc Biol 17:3557, 1997

14. Becker RC, Tracy RP, Bovill EG, Mann KG, Ault K: The clinical use of flow cytometry for assessing platelet activation in acute coronary syndromes. TIMI-III Thrombosis and Anticoagulation Group. Coron Artery Dis 5:339, 1994

15. Broijersen A, Karpe F, Hamsten A, Goodall AH, Hjemdahl P: Alimentary lipemia enhances the membrane expression of platelet P-selectin without affecting other markers of platelet activation. Atherosclerosis 137:107, 1998

16. Tsao P, McEvoy L, Drexler H, Cooke JP: Enhanced endo thelial adhesiveness in hypercholesterolemia is attenuated by L-arginine. Circulation 89:2176, 1994

17. Cybulsky MI, Gimbrone MA Jr: Endothelial expression of a mononuclear leukocyte adhesion molecule during atherogenesis. Science 251:788, 1991

18. Ott I, Neumann FJ, Gawaz M, Schmitt M, Schomig A: Increased neutrophil-platelet adhesion in patients with unstable angina. Circulation 94:1239, 1996

19. Mickelson JK, Lakkis NM, Villarreal-Levy G, Hughes BJ, Smith 
CW: Leukocyte activation with platelet adhesion after coronary angioplasty: A mechanism for recurrent disease? J Am Coll Cardiol 28:345, 1996

20. Merhi Y, Provost P, Guidoin R, Latour J-G: Importance of platelets in neutrophil adhesion and vasoconstriction after deep carotid arterial injury by angioplasty in pigs. Arthritis Thromb Vasc Biol 17:1185, 1997

21. Lehr HA, Oloffson AM, Carew TE, Vajkoczy P, von Andrian UH, Hübner C, Berndt MC, Steinberg D, Messmer K, Arfors KE: P-selectin mediates the interaction of circulating leukocytes with platelets and microvascular endothelium in response to oxidized lipoprotein in vivo. J Lab Invest 71:380, 1994

22. Kishimoto TK, Jutila MA, Butcher EC: Identification of a human peripheral lymph node homing receptor: A rapidly down-regulated adhesion molecule. Proc Natl Acad Sci USA 87:2244, 1990

23. de Bruijne-Admiral LG, Moddermann PW, Von dem Borne AEG $\mathrm{Kr}$, Sonnenberg A: P-selectin mediates $\mathrm{Ca}^{++}$dependent adhesion of activated platelets to many different types of leukocytes: Detection by flow cytometry. Blood 80:134, 1992

24. Civin CI, Trischmann TM, Fackler MJ, Schwartz JF, Shaper JH: Antigenic analysis of hematopoiesis. III. A hematopoietic progenitor cell surface antigen defined by a monoclonal antibody raised against KG-Ia cells. J Immunol 133:157, 1984

25. Deckmyn H, Stanssens P, Hoet B, Declerck PJ, Lauwereys M, Gansemans Y, Tornai I, Vermylen J: An echistatin-like Arg-Gly-Asp (RGD)-containing sequence in the heavy chain CDR3 of a murine monoclonal antibody that inhibits human platelet glycoprotein IIb/IIIa function. Br J Haematol 87:562, 1994

26. Holvoet P, Lijnen HR, Collen D: A monoclonal antibody specific for Lys-plasminogen. Application to the study of the activation pathways of plasminogen in vivo. J Biol Chem 260:12106, 1985

27. de St Groth SF, Scheidegger F: Production of monoclonal antibodies: Strategies and tactics. J Immunol Methods 35:1, 1980

28. Jaffe EA, Nachman RL, Becker CG, Minick CR: Culture of human endothelial cells derived from umbilical veins. J Clin Invest $52: 2745,1973$

29. Hubbell J, McIntire L: Technique for the visualization and analysis of mural thrombogenesis. Rev Sci Instrum 57:892, 1986
30. Levi M., Friederich PW, Middleton S, DeGroot PG, Wu YP, Harris R, Biemond BJ, Heijnen HFG, Levin J, Wouter ten Cate J: Fibrinogen-coated albumin microcapsules reduce bleeding in severely thrombocytopenic rabbits. Nat Med 5:107, 1999

31. Turrito VT, Baumgartner HR: Platelet interaction with subendothelium in a perfusion system: physical role of red blood cells. Microvasc Res 9:335, 1975

32. Palabrica T, Lobb R, Furie BC, Aronovitz M, Benjamin C, Hsu Y-M, Sajer SA, Furie B: Leukocyte accumulation promoting fibrin deposition is mediated in vivo by P-selectin on adherent platelets. Nature 359:848, 1992

33. Brown KK, Henson PM, Maclouf J, Moyle M, Ely JA, Worthen GS: Neutrophil-platelet adhesion: Relative roles of platelet P-selectin and neutrophil beta2 (DC18) integrins. Am J Respir Cell Mol Biol 18:100, 1998

34. Finger EB, Puri KD, Alon R, Lawrence MB, von Andrian UH, Springer TA: Adhesion through L-selectin requires a threshold hydrodynamic shear. Nature 379:266, 1996

35. Lawrence MB, Kansas GS, Kunkel EJ, Ley K: Threshold levels of fluid shear promote leukocyte adhesion through selectins. J Cell Biol 136:717, 1997

36. Barry OP, Pratico D, Savani RC, FitzGerald GA: Modulation of monocyte endothelial cell interactions by platelet microparticles. J Clin Invest 102:136, 1998

37. Luscinskas FW, Kansas GS, Ding H, Pizcueta P, Schleiffenbaum $\mathrm{BE}$, Tedder TF, Gimbrone MA: Monocyte rolling, arrest and spreading on IL-4-activated vascular endothelium under flow is mediated via sequential action of L-selectin, beta 1-integrins, and beta 2-integrins. J Cell Biol 125:1417, 1994

38. Butcher EC: Leukocyte-endothelial cell recognition: Three (or more) steps to specificity and diversity. Cell 67:1033, 1991

39. Bombeli T, Schwartz BR, Harlan JM: Adhesion of activated platelets to endothelial cells: Evidence for a GPIIbIIIa-dependent bridging mechanism and novel roles for endothelial intercellular adhesion molecule 1 (ICAM-1), $\alpha_{\nu} \beta_{3}$ integrin, and GPIb $\alpha$. J Exp Med 187:329, 1998 